Original Article

\title{
PHYTOCHEMICAL COMPOSITION AND EFFECT OF NAUCLEA LATIFOLIA AQUEOUS EXTRACTS ON BLOOD GLUCOSE LEVELS OF STREPTOZOTOCIN-INDUCED DIABETIC WISTAR ALBINO RATS
}

Ochalefu D.O ${ }^{1}$, Adoga G.I', Luka C.D ${ }^{2}$, Abu H.A ${ }^{3}$, Amali O.O.E ${ }^{1}$, Agada S.A ${ }^{1}$, Alonyenu E.I. ${ }^{1}$

Department of Medical Biochemistry, College of Health Sciences, Benue State University, Makurdi, Nigeria. ${ }^{I}$

Department of Biochemistry, Faculty of Medical Sciences, University of Jos, Jos, Nigeria. ${ }^{2}$

Department of Veterinary Physiology, Pharmacology and Biochemistry, College of Veterinary Medicine, University of Agriculture, Makurdi, Nigeria. ${ }^{3}$

* Corresponding Author: Dr. Ochalefu, Dickson Owoicho, Department of Medical Biochemistry, College of Health Sciences, Benue State University, Makurdi, Nigeria. Email:dickochalefu@gmail.com

Received date: April $30^{\text {th }} 2018$, Accepted date: June $3^{\text {th }}$ 2018. Published date: June $30^{\text {th }} 2018$

\section{Abstract}

Researches targeted at understanding and controlling abnormally high level of blood glucose in Diabetes mellitus are ongoing. In spite of many available anti-diabetic drugs in the market, safer and cheaper remedies from plant material are being sought for due to the unwanted side effects of these drugs. In this research work, we looked at the beneficial blood glucose lowering effect of the plant Nauclea latifolia in streptozotocin-induced diabetic albino Wistar rats. The extracts were first screened for the presence of phytochemicals using standard methods and the result showed the presence of saponins, tannins, reducing sugar, phlobatannins, anthraquinone, flavonoids, steroids and alkaloids. The study design involved 30 male albino Wistar rats which were divided into 6 groups. Groups 1 and 2 represent the Normal Control and Diabetic Control respectively. Groups 3, 4 and 5 were Diabetic rats treated orally with $500 \mathrm{mg} / \mathrm{kg}$ body weight of aqueous extracts of Stem-bark, Leaves and Root-bark respectively while Group 6 were Diabetic rats treated with $5 \mathrm{mg} / \mathrm{kg}$ body weight of Glibenclamide. The extracts and Glibenclamide were administered for 28 days. Blood glucose levels were determined on days $0,7,14,21$ and 28 by tail tipping method using Glucometer (Accu-Chek, Manheim, Germany). The extracts and Glibenclamide reduced significantly $(\mathrm{p}<0.05)$ the Fasting Blood Glucose levels in the diabetic treated rats compared with the Diabetic Control. Amongst the extracts the root-bark is more efficacious, decreasing the glucose level by $49.80 \%$ while the stem-bark and leaves brought about reduction by $28.76 \%$ and $12.15 \%$ respectively. The findings imply that the extracts of this plant have blood glucose lowering ability and should be further evaluated for its beneficial effect in Diabetes mellitus management.

Keywords: Aqueous extracts, Blood glucose, Diabetes mellitus, Nauclea latifolia, Phytochemicals

\section{Introduction}

Diabetes mellitus is a diverse and chronic metabolic disease of the endocrine system which causes alteration in glucose, protein and lipid metabolism. ${ }^{1,2,3}$ It is linked with abnormality of high blood glucose level due to absence or inadequate insulin secretion with or without deterioration of insulin action. ${ }^{4,5}$ The disease is secondary to a reduction or damage to the $\beta$ cells of the islets of Langerhans in the pancreas or resistance of the tissues to insulin which aids the entrance of the glucose into the tissues. ${ }^{3}$ This precipitates a situation whereby despite ample supply of glucose, the tissues are not getting it and the body behaves as being starved. This leads to overproduction of glucose through gluconeogenesis in the liver. There is, therefore, abnormally high level of blood glucose (Hyperglycaemia) which may overwhelm the kidneys capacity to reabsorb, with spillover of the excess glucose into the urine (Glucosuria). ${ }^{2}$ Chronic hyperglycaemia in Diabetes mellitus is associated with destruction, malfunctioning and failure of the various organs in the body such as kidney, eye, nerve, heart and blood vessels. ${ }^{6}$ This ailment has led to many 
premature deaths. It has also caused permanent disabilities like blindness and limb amputation. ${ }^{7,8,9}$ Diabetes mellitus is rapidly increasing worldwide. The total number of adults between the ages of 20-70 years estimated to have the disease globally by the International Diabetes Federation (IDF) in 2012 was 366 million and led to the death of 4.6 million people. ${ }^{10,11}$ In 2013, IDF put the estimate of people having Diabetes mellitus to be 381 million. This figure is projected to double by $2030 .^{12}$

At the moment the available drugs for the management of diabetes mellitus include insulin and other anti-diabetic drugs which include the glucosidase inhibitors, the biquanides and sulfonyureas. The use of these drugs is associated with some serious side effects like gastrointestinal reactions, hypoglycaemic coma and interference with kidney and liver functions. ${ }^{13}$ The drawback of these drugs has increased the use of traditional and complementary medicines. Plant parts with the claim of hypoglycaemic properties for management of Diabetes mellitus have been used traditionally since ancient times around the world. ${ }^{14,15}$

A number of investigations have shown that secondary metabolites like saponins, flavonoids and tannins that are present in plants possess hypoglycaemic effect on various animal models. The quantity and quality of these metabolites present in plant parts may differ from one part to another. ${ }^{16,17}$ The plant Nauclea latifolia (African peach) called Oya among the Idoma natives, kyuraukase in Tiv, ${ }^{18}$ Tafashiya among the Hausas, ${ }^{19}$ Mbom-Ibom in both Cross River and Akwa Ibom States and Ubuluinu in Igbo land ${ }^{20}$ is widely used by traditional healers in Idoma land of Benue State, Nigeria for the management of diabetes mellitus. Although all parts of the plant are used, several Idoma diabetic patients have confirmed the efficacy of the root-bark extract. Nauclea latifolia is an evergreen multi-stemmed shrub or a tree. It grows up to a height of between 10 metres to 30 metres. Its natural habitat is the humid tropical rain forest zone or the savannah wood lands of West and Central Africa. ${ }^{21}$ See Fig. 1

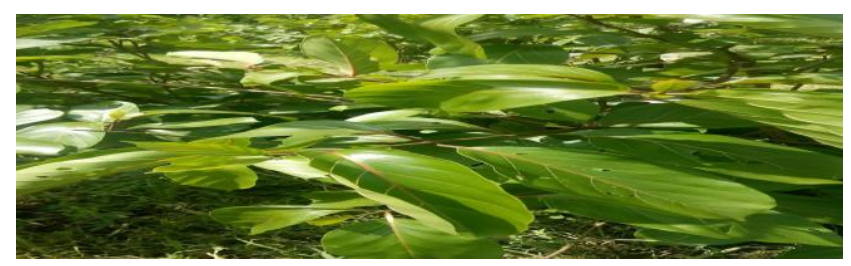

Fig.1 Nauclea latifolia plant.

\section{Materials and Methods}

\section{Collection and preparation of plant materials}

The plant material was harvested from the environs of the Federal University of Agriculture, Makurdi, Benue State, Nigeria. The plant was identified and authenticated by Mr. J. J Azila of the Federal School of Forestry, Jos, Plateau State, Nigeria where the voucher number FHJ 279 was assigned. Samples of the plant were deposited at the school's herbarium.

\section{Preparation of extracts}

The leaves, stem-bark and root-bark were air- dried at room temperature, pulverized using pestle and mortar and stored in air-tight containers until the time of use. One hundred grammes (100g) of the leaves, stem-bark and root-bark powder were separately weighed using an electronic weighing machine (Mettler Toledo). The leaves, stem-bark and root-bark powder were separately soaked in $1000 \mathrm{ml}$ of distilled water at a ratio of 1:10 (powder/solvent) ${ }^{22}$ These were stirred intermittently for 48 hours at room temperature. The soaked powder was filtered using muscilin cloth after which sterile cotton wool and Whatman filter paper No 1 size $110 \mathrm{~mm}$ were used to obtain a pure filtrate. The filtrates were then separately concentrated to dryness using water bath at temperature of $45^{\circ} \mathrm{C}$ yielding $13.30 \mathrm{~g}(13.3 \%), 11.09 \mathrm{~g}(11.09 \%)$ and $15.02 \mathrm{~g}$ $(15.02 \mathrm{~g})$ for leaves, root-bark and stem-bark respectively. The extracts were then stored in the refrigerator from where aliquots were used for the study. expression:

The percentage yield was calculated by the

$$
\% \text { yield }=\frac{\text { Weight of extract }(\mathrm{g})}{\text { Weight of dry sample }(\mathrm{g})} \mathrm{X}
$$

\section{Research design}

\section{Phytochemical analysis}

Qualitative analysis was carried out for each of the extracts. The following phytochemicals: saponins, tannins, reducing sugar, phlobatanins, anthraquinones, flavonoids, steroids and alkaloids were tested for, using the methods of Odebiyi and Sofowora. ${ }^{23}$

\section{Animal studies}

Male albinoWistar rats weighing between 153.5177 grammes used for the study were obtained from the Animal House, College of Health Sciences, Benue State University, Makurdi, Nigeria. They were kept in 
polypropylene cages under room temperature, with 12-hour light and 12-hour dark cycle. They were allowed to acclimatize for two weeks before the commencement of the experiment. The rats were divided into six groups of five rats each. Group A was Normal Control and Group B was streptozotocininduced Diabetic Control. The controls were administered $1 \mathrm{ml}$ distilled water orally. Groups C, D and $\mathrm{E}$ were streptozotocin-induced diabetic rats treated with $500 \mathrm{mg} / \mathrm{kg}$ body weight of stem-bark, leaves and root-bark extracts of Nauclea latifolia respectively for 28 days and group $\mathrm{F}$ was streptozotocin-induced diabetic rats treated with $5 \mathrm{mg} / \mathrm{kg}$ body weight of the standard anti-diabetic drug, Glibenclamide by Sanofi Aventis, Nigeria Limited, daily for 28 days. $^{3}$ The extracts and glibenclamide were administered orally through intrapharyngeal feeding canula. The rats were fed ad libitum with pellet diet (Grand Cereals Ltd, Jos, Nigeria) and clean tap water. Good hygiene was maintained by constant cleaning and removal of faeces and spills from cages daily. The experiment was conducted between the hours of 9.00 A.M and 11 A.M. The protocols for these experiments were in accordance with the ethical guidelines on the care and use of laboratory animals. ${ }^{24}$

\section{Acute oral toxicity}

The acute oral toxicity study was conducted using limit dose test of revised Up- and- Down procedure. ${ }^{25}$ Five female rats one at a time were administered $5000 \mathrm{mg} / \mathrm{kg}$ body weight of Nauclea latifolia extracts ( separate administration for leaves, stem-bark and rootbark extracts ) after overnight fast of food.

Each rat was observed each time for the first 5 minutes after dosing for signs of regurgitation and then kept in the cage and watched for every 15 minutes in the first 4 hours and then every 30 minutes for the successive 6 hours. Thereafter, observations were made daily for 14 days in case of delayed toxicity.

\section{Induction of Diabetes Mellitus}

Diabetes mellitus was induced in overnight fasted rats weighing between 153.5-177.0 grammes by single intra-peritoneal injection of freshly prepared Streptozotocin (Sigma-Aldrich, Germany) $60 \mathrm{mg} / \mathrm{kg}$. body weight in $0.1 \mathrm{M}$ citrate buffer $(\mathrm{pH} 4.5){ }^{26,27,28}$ Diabetes was confirmed in the streptozotocin treated rats by measuring fasting blood glucose concentration using Glucometer (Accu-Chek, Mannheim, Germany) 48 hours after streptozotocin injection. Rats with fasting blood glucose of more than $200 \mathrm{mg} / \mathrm{dl}$ were considered diabetic and used for the study.

\section{Evaluation of the hypoglycaemic activity of the aqueous extracts of Nauclea latifolia}

The aqueous extracts of the stem-bark, leaves and root-bark were orally administered through intrapharyngeal feeding canula to the diabetic rats at a dose of $500 \mathrm{mg} / \mathrm{kg}$ body weight after determining their initial fasting blood glucose concentration. The extracts and the standard anti-diabetic drug, glibenclamide, at $5 \mathrm{mg} / \mathrm{kg}$ body weight were administered daily for a period of twenty-eight days. ${ }^{5}$ Blood was collected from the experimental rats for the determination of fasting blood glucose levels on days $0,7,14,21$ and 28 by tail tipping method. The blood sample was taken through a small incision on the tail tip. The blood was dropped on the dextrostix reagent pad which was inserted into the digital glucometer (Accu-Chek, Mannheim, Germany) and the readings were recorded.

\section{Statistical analysis}

Statistical analysis was done using the statistical package for social sciences (SPSS). The results were expressed as Mean \pm SEM (Standard error of mean), where $n=5$, analyzed by One -Way Analysis of Variance (ANOVA) and the level of significance determined by least significant difference (LSD). The $\mathrm{p}$ values of 0.05 and less were taken to imply statistical significance between the means.

\section{Results}

\section{Percentage yield of the extracts}

The percentage yields of the aqueous extracts of stembark, leaves and root-bark of Nauclea latifolia are $15.02 \%, 13.30 \%$ and $11.09 \%$ respectively (Table 1). The phytochemical constituents of the leaves, stembark and root-bark extracts of Nauclea latifolia are shown on Table 2. The results show the presence of the active phytochemicals in the leaves, stem-bark and root-bark extracts. The leaves, stem-bark and rootbark of the plant contain saponins, reducing sugar, anthraquinone, flavonoids and alkaloids. Tannin is present in the leaves but absent in the stem-bark and root-bark. Steroid and Phlobatanin are present in both stem-bark and root-bark but absent in the leaves. 
Table 1: Percentage yields of leaves, stem-bark and root-bark Aqueous extracts of Nauclea latifolia

\begin{tabular}{llll}
\hline Extract & Weight of dry sample(g) & Weight of extract $(\mathbf{g})$ & \% Yield of extract \\
\hline Stem-bark & 100 & 15.02 & 15.02 \\
Leaves & 100 & 13.30 & 13.30 \\
Root-bark & 100 & 11.09 & 11.09 \\
\hline
\end{tabular}

Table 2: Results of qualitative phytochemical screening of the leaves, stem-bark and root-bark extracts of Nauclea latifolia

\begin{tabular}{llcc}
\hline Phytochemical & Leaves & Stem-bark & Root-bark \\
\hline Saponins & $+\mathrm{ve}$ & $+\mathrm{ve}$ & $+\mathrm{ve}$ \\
Tannins & $+\mathrm{ve}$ & $-\mathrm{ve}$ & $-\mathrm{ve}$ \\
Reducing sugar & $+\mathrm{ve}$ & $+\mathrm{ve}$ & $+\mathrm{ve}$ \\
Phlobatanins & $-\mathrm{ve}$ & $+\mathrm{ve}$ & $+\mathrm{ve}$ \\
Anthraquinone & $+\mathrm{ve}$ & $+\mathrm{ve}$ & $+\mathrm{ve}$ \\
Flavonoids & $+\mathrm{ve}$ & $+\mathrm{ve}$ & $+\mathrm{ve}$ \\
Steroids & $-\mathrm{ve}$ & $+\mathrm{ve}$ & $+\mathrm{ve}$ \\
Alkaloids & $+\mathrm{ve}$ & $+\mathrm{ve}$ & $+\mathrm{ve}$ \\
\hline
\end{tabular}

Key: +ve = Present; -ve= Absent

Table 3: Effects of aqueous extracts of stem-bark, leaves and root- bark of Nauclea latifolia and glibenclamide (standard anti-diabetic drug) on Fasting Blood Glucose (FBG) in streptozotocin-induced diabetic Wistar Albino Rat

\begin{tabular}{|c|c|c|c|c|c|}
\hline Treatment & & & Duration & & \\
\hline & $\begin{array}{l}\text { Day 0 } \\
\text { (mg/dl) }\end{array}$ & $\begin{array}{l}\text { Day } 7 \\
\text { (mg/dl) }\end{array}$ & $\begin{array}{l}\text { Day } 14 \\
\text { (mg/dl) }\end{array}$ & $\begin{array}{r}\text { Day } 21 \\
\text { (mg/dl) }\end{array}$ & $\begin{array}{c}\text { Day 28 } \\
(\mathrm{mg} / \mathrm{dl})\end{array}$ \\
\hline A Normal control & $81.80 \pm 19.56$ & $85.80 \pm 10.56$ & $89.40 \pm 17.16$ & $81.20 \pm 9.26$ & $86.00 \pm 12.25$ \\
\hline B Diabetic control & $356.80 \pm 48.62$ & $399.40 \pm 40.33 * *$ & $446.00 \pm 47.52 * *$ & $426.20 \pm 29.90 * *$ & $438.20 \pm 49.25^{* *}$ \\
\hline C Stem-bark extract & t $369.20 \pm 37.96$ & $336.60 \pm 40.66^{*}$ & $343.20 \pm 19.06 *$ & $323.80 \pm 27.45 *$ & $263.00 \pm 24.33 *$ \\
\hline D Leaves extract & $388.40 \pm 24.40$ & $358.00 \pm 21.49 *$ & $349.00 \pm 20.19 *$ & $340.20 \pm 23.74 *$ & $341.20 \pm 20.24 *$ \\
\hline E Root-bark extract & $372.00 \pm 21.20$ & $223.40 \pm 30.02 *$ & $193.80 \pm 19.77^{*}$ & $168.80 \pm 34.10 *$ & $186.80 \pm 15.07 *$ \\
\hline F Glibenclamide & $379.00 \pm 36.24$ & $226.80 \pm 39.38 *$ & $214.60 \pm 49.29 *$ & $183.40 \pm 22.42 *$ & $149.00 \pm 38.86^{*}$ \\
\hline
\end{tabular}

Values are Mean \pm SEM of 5 determinations.

$*=$ Statistically significant when compared to diabetic control at $(p<0.05)$

$* *=$ Statistically significant when compared to normal control at $(p<0.05)$

Table 4: Percentage (\%) reduction of Fasting Blood Glucose levels by aqueous extracts of stem-bark leaves and root-bark of Nauclea latifolia and Glibenclamide drug in streptozotocin induced Diabetic Wistar Albino Rats

\begin{tabular}{lccc}
\hline Treatment & $\begin{array}{c}\text { Day 0 } \\
(\mathrm{mg} / \mathrm{dl})\end{array}$ & $\begin{array}{l}\text { Day 28 } \\
(\mathrm{mg} / \mathrm{dl})\end{array}$ & \% Reduction of blood glucose \\
\hline Stem-bark extract & $369.20 \pm 37.96$ & $263.00 \pm 24.33$ & 28.76 \\
Leaves extract & $388.40 \pm 24.40$ & $341.20 \pm 20.24$ & 12.15 \\
Root-bark extract & $372.00 \pm 21.20$ & $186.80 \pm 15.07$ & 49.80 \\
Glibenclamide drug & $379.00 \pm 36.24$ & $149.00 \pm 38.86$ & 60.68 \\
\hline
\end{tabular}

\section{Results of acute toxicity studies}

The results of the acute oral toxicity studies carried out using the aqueous extracts of the leaves, stem-bark and root-bark of Nauclea latifolia showed that there was no mortality in the rats when the dose of $5000 \mathrm{mg} /$ $\mathrm{Kg}$ body weight of extracts were orally administered respectively within the short and long term outcome of the limit dose of the Up- and- Down procedure. The aqueous extracts had no untoward effect on the nervous system since the rats did not convulse. Adverse changes in behaviour, breathing, stool, urine and mucous membrane were not observed within the period.

\section{Results of Fasting Blood Glucose levels}

Table 3 shows significant increase $(p<0.05)$ of the fasting blood glucose levels of the diabetic control rats compared with the normal control rats. The administration of aqueous extracts of leaves, stembark and root-bark of Nauclea latifolia and standard anti-diabetic drug, glibenclamide, significantly lowered ( $p$ <0.05) the fasting blood glucose levels compared with the diabetic control rats.

Glibenclamide reduced the fasting blood glucose levels in the diabetic rats by $60.68 \%$ while the aqueous extracts of the stem-bark, leaves and the rootbark reduced the fasting blood glucose by $28.76 \%$, $12.15 \%$ and $49.80 \%$ respectively. The root-bark 
extract is more efficacious in lowering blood glucose level compared to the leaves and stem-bark extracts (Table 4).

\section{Discussion}

The detection of the secondary metabolites, saponins, tannins, reducing sugar, phlobatannins, anthraquinones, flavonoids, steroids and alkaloids in the aqueous extracts of Nauclea latifolia in the study agrees with the findings of the research work of Yesufu et al, Maitera et al and Arise et al. They found out that Nauclea latifolia plant contains these phytochemicals. $^{29,30,31}$ The presence of flavonoids, saponins, alkaloids and tannins in plant extracts have been reported to be responsible for blood glucose lowering activity. ${ }^{5,32,33,34,35}$

The lack of mortality of the experimental rats at limit dose of $5000 \mathrm{mg} / \mathrm{kg}$ body weight implies that the aqueous extracts of this plant have low toxicity when administered orally. This finding concurs with the reports of Assam et al who administered Nauclea latifolia ethanolic extract to mice at $8000 \mathrm{mg} / \mathrm{kg}$ body weight and found no major signs of toxicity within the observation time. ${ }^{36}$ The finding of the work done by Effiong and Akpan that Nauclea latifolia administered to rats produced no lethality even at doses as high as $8000 \mathrm{mg} / \mathrm{kg}$ body weight is in consonance with our finding. ${ }^{37}$

Intra-peritoneal streptozotocin injection to the experimental rats causing significant rise in blood glucose level agrees with the reports of research works done by Moore et al, Maiti et al, Beppu et al and Rekha et al in which they independently administered intra-peritoneal streptozotocin injection to experimental rats and found elevated blood glucose levels $38,39,40,14$

The use of streptozotocin caused damage to the majority of the $\beta$ - cells of islets of Langerhans leading to pancreatic dysfunction. This causes low insulin with subsequent increase in the blood glucose level. ${ }^{14}$ Streptozotocin action on the pancreas causes $\beta$ - cells destruction by necrosis. ${ }^{3}$ The mechanism of action of streptozotocin in causing elevated blood glucose is thought to be through its entry into the $\beta$-cells via a glucose transporter (GLUT 2) where it leads to alkylation of DNA molecule and its eventual destruction. DNA destruction induces the activation of poly- ADP- ribosylation. Poly-ADP- ribosylation causes depletion of cellular nicotinamide adenine dinucleotide $\left(\mathrm{NAD}^{+}\right)$and adenosine triphosphate
(ATP). Enhanced ATP dephosphorylation after streptozotocin treatment supplies a substrate for xanthine oxidase leading to the formation of superoxide radicals, hydrogen peroxide radicals and hydroxyl radicals in vivo. ${ }^{3,41}$ Streptozotocin also releases toxic amounts of nitric oxide into the body and this prevents aconitase enzyme activity and participates in DNA destruction. Because of the streptozotocin action, the $\beta$-cells of islets of Langerhans undergo damage by necrosis. ${ }^{41}$

Our result of significant decrease in the blood glucose levels of the diabetic rats administered aqueous extracts of Nauclea latifolia and glibenclamide is similar to earlier reports by Luka and Tijjani and Okonkwo and Okoye. They found out that plant extracts have blood glucose lowering effect on diabetic rats. ${ }^{42,43}$

The likely mechanism by which the aqueous extracts caused the lowering of the blood glucose in the diabetic treated rats may be by induction of pancreatic insulin secretion from the remaining $\beta$-cells of islets of Langerhans or due to improved transport of blood glucose into the peripheral tissues. ${ }^{44}$ It is also said that extracts most likely have similar mechanism of action like Glibenclamide in terms of blood glucose lowering ability by inhibiting the sulphonylurea receptor 1 (SUR 1) the regulatory subunit of the ATP- sensitive potassium channels (KATP) in the pancreatic beta cells. This inhibition results in cell membrane depolarization with subsequent opening of the voltage dependent calcium channel. This causes elevation of the intracellular calcium in the $\beta$-cells resulting in stimulation of insulin release and subsequent lowering of the blood glucose level. ${ }^{45}$

\section{Conclusion}

This study showed that the phytochemicals, saponins, tannins, reducing sugar, phlobatanins, anthraquinone, flavonoids, steroids and alkaloids are present in the plant Nauclea latifolia. This plant has been seen to have blood glucose lowering ability with the root-bark extract being more effective. Furthermore, the aqueous extracts are tolerated and showed no adverse effects. This study validates the claim of the natives regarding the use of the root-bark extract in the management of type 2 diabetes mellitus. 


\section{Recommendations}

The blood glucose lowering ability of Nauclea latifolia extracts makes it a plant with a potential for diabetes mellitus management. Therefore, further investigation with an aim to identifying its active principles is essential as this will help in probable drug making out of it.

\section{References}

1. Van den B G; William A; Hermas G; Meersseman W; Wonters P.J; Milants I et al. Intensive insulin therapy in the medicinal ICU. N. Engl. J. Med. 2006: 354 (5): 449-461.

2. Robert H H; Lawrence A; Moran K G; Scrimgeor M P; David J R. Principles of Biochemistry. Fourth edition. 2006: page 516.

3. Effiong E E; Igile G O; Mgbeje B I A; Otu E A; Ebong P E. Hepatoprotective and anti-diabetic effect of combined extracts of Moringa oleifera and Vernonia amygdalina in streptozotocin-induced diabetic albino wistar rats. Journal of Diabetes and Endocrinology. 2013:4(4):45-50.

4. Rang H P; Dale M M; Ritter J M; Flower RJ. Rang and Dele's Pharmacology. $6^{\text {th }}$ edn. 2007: pp. 402-408.

5. Omonkhelin J O; Silvanus O I; Ogochukwu N A; Osaretin A I. Antidiabetic and hypolipidaemic effects of methanol leaf extract of Napoleona vogelli (Lecythidaceae) hook and planch in alloxan-induced diabetic mellitus in rats. Tropical Journal of Pharmaceutical Research. 2014: 13 (11): 1903-1909.

6. American Diabetes Association, ADA. Diagnosis and classification of diabetes mellitus. Care. 2009: 3(1): S62-S67.

7. Adoga G I; Ohaeri C O; Aliyu S I. The incidence of sickle cell anaemia among diabetic patients in Jos, Nigeria. Med. Sci. Research. 1995: 23: 475-476.

8. Oputa R N; Chinenye S. Diabetes in Nigeria- a traditional medicine approach. African Journal of Diabetes Medicine. 2015: 23(1): 7-10.

9. International Diabetes Federation Atlas (6 ${ }^{\text {th }}$ Edition). International Diabetes Federation. 2013: Available at $\mathrm{htt} / / \mathrm{www}$.idf.org/diabetes atlas.

10. International Diabetes Federation, IDF. Clinical guideline. Task Force global guideline for type 2 diabetes mellitus. IDF. 2012.

11. Hu F B. Globalization of diabetes mellitus. The role of diet, life style and genes. Diabetes Care. 2011: 34: 1249-1257.

12. Ayinla M T ; Owoyele B V; Yakubu M T. Antidiabetic activity of aqueous extract of Senna fistula leaves in streptozotocin-induced diabetic rats. Nigerian Journal of Biochemistry and Molecular Biology. 2014: 29(2): 93-106.
13. Jardin J; Trindale E; Carneiro F; Dias J A. Hepatomegaly in type 1 diabetes mellitus: When a suspect of glycogenic hepatopathy? Journal of Medical Cases. 2013:4(11): 726-728.

14. Rekha N; Balagi R; Deecaraman $M$. Antihyperglycaemic and antihyperlipidaemic effects of extracts of the pulp of Syzygium cumini and bark of Cinnamon zeylanicum in streptozotocin-induced diabetic rats. Journal of Applied Biosciences. 2010: 28; 1718-1730.

15. Huang T H; Kota B P; Razmouski V; Ronfogalis B D. Herbal or natural medicines as modulators of peroxisome proliferator- activated receptors and related nuclear receptors for therapy of metabolic syndrome. Basic and Clinical Pharmacology and Toxicology. 2005: 96: 3-14.

16. Sexena A; Kishore V N. Role of selected medicinal Indian plants in management of type 2 diabetes. A review. J. Alternat. Complement Medicine. 2004: 10(2): 369-378.

17. Hatil H E; Ahmed A E. Preliminary phytochemical screening of 27 plants species used in ethnoveterinary in Khartoum State, Sudan. Advances in Life Sciences. 2015:5(2): 48-52.

18. Agishi E C. Tiv, Idoma, Etulo, Igede, Akweya, Hausa, English and Scientific names of plants. Second Edition. 2010: Page 19.

19. Gidado A; Ameh D A; Atawodi S E; Ibrahim S. Hypoglycaemic activity of Nauclea latifolia (Rubiaceae) in experimental animals. African Journal of Traditional Complementary Alternative Medicine. 2008: 5: 201-208.

20. Akpanabiatu M I; Umoh I B; Udosen E O; Udoh A E; Edet E E. Rat serum electrolytes, lipid profile and cardiovascular activity of Nauclea latifolia leaf extract administration. Indian Journal of Clinical Biochemistry. 2005: 20(2): 29-34.

21. Okwori A E J; Okeke C I; Uzoechina A; Etukudoh N S; Amali M N; Adetunji J A et al. The anti-diabetic potentials of Nauclea latifolia. African Journal of Biotechnology. 2008: 7(10): 1394-1399.

22. Das K; Tiwari R K S; Shrivastava D K. Techniques for evaluation of medicinal plants products as antimicrobial agent: Current methods and future trends. Journal of Medicinal Plants Research. 2010:4(2): 104111.

23. Odebiyi A; Sofowora E A. Phytochemical screening of Nigerian medicinal plants part III. Liyodia. 1978: 403: 234-246.

24. National Institute of Health, NIH. Consensus statement. 1985: 5(11):1-23.

25. OECD. Test guidelines 425 . Acute oral toxicity. Up and- Down procedure. 2001.

26. Adoga G I; Ibrahim M B. Effect of garlic oil on some biochemical parameters in streptozotocin-induced diabetic rats. Med. Sci. Research. 1990: 18: 859-860. 
27. Ghoraishian S M. the effect of Hazel leaf decoction on blood glucose reduction in the diabetic rats. World Journal of Medical Sciences. 2006: 1(2): 144-146.

28. Rao P V; Naido M D. Anti-diabetic effect of Rhinacanthusnasutus leaf extract in streptozotocininduced diabetic rats. Libyan Agricultural Research Centre. Journal International. 2010: 1: 310-312.

29. Yesufu H B; Bassi P U; Khan I Z; Abdulrahaman F I; Mohammed G T. Phytochemical screening and hepatoprotective properties of the aqueous root-bark extract of sarcocephalus latifolius. Achives of Clinical Microbiology. 2010: vol.1. No 23.

30. Maitera O N; Khan M E; James T F. Phytochemical analysis and the chemotherapeutics of leaves and stembark of Nauclea latifolia grown in Hong, adamawa State, Nigeria, Asian Journal of Plant Sciences and Research. 2011: 1(3): 16-22.

31. Arise R O; Akintola A A; Olarinoye J B; Balogun E A. Effects of aqueous extract of Nauclea latifolia stembark in lipid profile and some enzymes of rat liver and kidney. International Journal of Pharmacology. 2012: 8: 389-395.

32. Sherma R D; Sarkhar D K; Hazra M B. Toxicological evaluation of Fenngreek seeds: a long term feeding experiment in diabetic patients. Phytother. Res. 2010: 10: 519-520.

33. Nimenido- Uadia R. The effect of Vernonia amygdalina in alloxan-induced diabetic albino rats. Journal of medicinal Sciences. 2003: 12 (1): 25-31.

34. Li W L; Zheng H C; Bukuru J; De-Kimpe N. Natural medicine used in traditional Chinese medicinal system for therapy of diabetes mellitus. Journal of Ethnopharmacology. 2004: 92: 1-21.

35. Ojewole J D. Hypoglycaemic effects of Clausena anisata hook methonolic root extract in rats. Ethnopharmacology. 2002: 81: 231-237.

36. Assam J P; Dzoyem C A; Pieme V B; Penlap P. In vitro anti-bacterial activity and acute toxicity studies of aqueous methanol extract of Sida rhombifolia linn (Mallvaleae) B M C Complementary and Alternative Medicine. 2010: 10:40.
37. Effiong G S; Akpan H D. The effect of Nauclea latifolia leaf extract in some biochemical parameters in streptozotocin-induced diabetic rat models. Journal of Medicine and Medicinal Science. 2015: 6(3): 47-52.

38. Moore M C; Coate K C; Winnick J J; Zhibo A N; Charrinton A D. Regulation of hepatic glucose uptake and storage in vivo. In thematic review series: Nutrient control of metabolism and cell signaling. American Society for Advance Nutrition. 2012:3: 286-294.

39. Maiti R; Jana D; Das U K; Ghoshi D. Anti- diabetic effect of aqueous extract of seed of Tarmarindus indica in streptozotocin induced diabetic rats. Journal of Ethnopharmacology. 2004: 92: 85-91.

40. Beppu H; Shimpo K; Chihara T; Kaneko T; Tamai I; Yamaji $S$ et al. Anti-diabetic effects of dietary administration of Aloe arborescens. Miller components in multiple low dose streptozotocin-induced diabetes mellitus in mice: Investigation on hypoglycaemic action and systemic absorption dynamics of Aloe components. Journal of Ethnopharmacology. 2006: 103: 468-477.

41. Szkudelski T. The mechanism of alloxan and streptozotocin action in $\beta$-cells of the rat pancreas. Physiol. Res. 2001: 50(6): 537-546.

42. Luka C D; Tijjani H. Comparative studies of aqueous extracts of Ocimum gratissimum, Aloe vera, Bassica oleracea and Ipommoea botatal on some biochemical parameters in diabetic rats. IOSR Journal of Pharmacy and Biological Science. 2013: 6(3): 23-29.

43. Okonkwo P O; Okoye Z S C. Hyperglycaemic effects of aqueous extract of Newbouldia laevis root in rats. International Journal of Biological Chemical Science. 2009:3(5): 998-1004.

44. Iwueke A V; Nwodo F O. Anti-diabetic effect of Sarcocephalus latifolius aqueous root extract in experimental rats' model. Animal Research International. 2007: 4(2): 698-701.

45. Lee M S; Sohn C B. Antidiabetic properties of Chrysophanol and its glucoside from Rhubarb rhizome. Biological Pharm. Bull. 2008: 31(11): 2154-2157. 